\title{
UCZEŃ ZDOLNY MATEMATYCZNIE W SZKOLE BIAŁORUSKIEJ
}

\begin{abstract}
Abstrakt: Białoruska szkoła należy do tradycyjnych systemów edukacji. Mimo to pewne jej dziedziny nadal są wydajne. Do takowych należą m.in. ukierunkowana opieka szkolna nad uczniami nadzwyczajnie utalentowanymi matematycznie oraz różne sposoby formowania osobowości dzieci uzdolnionych. O skuteczności tych dziedzin decyduje system edukacji na Białorusi zależny od rozmaitych czynników, które wpływają na kształtowanie młodych talentów. Świadectwem pozytywnego działania wspierania rozwoju uczniów wybitnie uzdolnionych matematycznie w tym kraju są ich osiągnięcia na międzynarodowych olimpiadach z matematyki i informatyki.
\end{abstract}

Słowa kluczowe: uzdolnienia matematyczne, edukacja, Białoruś

\section{WPROWADZENIE}

Czy dziecko uzdolnione jest dzieckiem ze specjalnymi potrzebami edukacyjnymi? W Polsce w myśl Ustawy z dnia 7 września 1991 r. o systemie oświaty władze publiczne powinny zapewnić zwłaszcza „opiekę nad uczniami szczególnie uzdolnionymi poprzez umożliwianie realizowania indywidualnych programów nauczania oraz ukończenia szkoły każdego typu w skróconym czasie" (art. 1, pkt 6). Mając na uwadze wsparcie zdolnych dzieci w Polsce, Ministerstwo Edukacji Narodowej ogłosiło rok szkolny 2010/2011 rokiem odkrywania talentów. Na stronie internetowej MEN znalazło się zaproszenie do udziału w naborze ekspertów z zakresu pracy z uczniem zdolnym do projektu „Opracowanie i wdrożenie kompleksowego systemu pracy z uczniem zdolnym" realizowanego przez Ośrodek Rozwoju Edukacji (ORE) 
od 1 lipca 2011 roku do 31 grudnia 2014 roku. Działania w ramach projektu, ich cele i obszary zaprezentowała koordynator Teresy Kosiarek na konferencji w Ożarowie Mazowieckim w maju 2013 roku. Na stronie internetowej ORE opublikowane są uporządkowane narzędzia do diagnozy zdolności, predyspozycji uczniów zdolnych, które powstały jako pomoc dla nauczycieli w identyfikacji ucznia zdolnego. Podjęte działania potwierdzają, że dziecko uzdolnione jest dzieckiem ze specjalnymi potrzebami edukacyjnymi. Czy z podobnego założenia wychodzi się w innych państwach?

W związku z różnicami w systemach edukacyjnych w Polsce i na Białorusi wymiana doświadczeń oraz wiedza na temat dzieci uzdolnionych może być bardzo korzystna dla obu krajów. Celem niniejszego artykułu jest przedstawienie walorów edukacji w szkole białoruskiej związanych ze skuteczną opieką nad dziećmi utalentowanymi matematycznie.

\section{UCZEŃ ZDOLNY - PRÓBA DEFINICJI}

Jakich uczniów nazywamy zdolnymi? Z raportu Helsińskiej Fundacji Praw Człowieka (Ciechanowski i in. 2010), który zawiera analizę odpowiedzi dyrektorów i pedagogów szkolnych w Polsce, jednoznacznie wynika, że nie tylko nie ma zgody co do definicji ucznia szczególnie uzdolnionego, ale nawet przybliżonych wspólnych kryteriów wyłaniania takich uczniów. Jednak zasadnicza większość respondentów indywidualne uzdolnienia rozumie jako talenty w zdobywaniu wiedzy w różnych obszarach, a ucznia szczególnie zdolnego jako ucznia bardzo inteligentnego lub/i posiadającego jakieś wyjątkowe talenty (Ciechanowski i in. 2010).

W psychopedagogicznych ujęciach uczniów zdolnych najczęściej definiuje się za Sydneyem Marlandem, że są to:

dzieci/uczniowie, którzy przejawiają możliwości zaawansowanych dokonań w dziedzinie: umysłowej, twórczej, artystycznej, w zakresie zdolności przywódczych czy w poszczególnych przedmiotach nauczania i które w celu pełnego rozwinięcia tych możliwości wymagają usług lub zajęć niedostarczanych przez standardową szkołę (Ebby, Smutny 1998, s. 15).

W definiowaniu uczniów zdolnych można wyróżnić trzy ujęcia (Kosiarek 2013):

- pedagogiczne: uczeń zdolny to taki, który osiąga najwyższe oceny szkolne oraz bardzo dobre wyniki w konkursach,

- psychologiczne: uczeń zdolny cechuje się wybitnymi zdolnościami intelektualnymi. Charakterystyka ta jest zwykle uzupełniana o diagnozę cech osobowości (przeważnie motywacji i temperamentu), 
- pedagogiczne-psychologiczne: uczeń zdolny ma szczególne osiągnięcia.

Charakterystyka ta uzupełniana jest o właściwości motywacji i funkcjonowania społecznego.

$\mathrm{Na}$ Białorusi dzieci uzdolnione rozwijają swoje talenty w takich instytucjach oświatowych jak gimnazjum i liceum. W szkołach tego typu stosuje się następującą definicję pojęcia uzdolnienia:

Uzdolnienie to jest systemowa, rozwijająca się w ciągu życia właściwość psychiki, która determinuje możliwość osiągnięcia przez człowieka bardzo wysokich, ponadprzeciętnych wyników w jednej lub kilku dziedzinach w porównaniu do innych osób. Dziecko uzdolnione to dziecko, które wyróżnia się wyraźnymi, oczywistymi, nieraz wybitnymi osiągnięciami (albo posiada wewnętrzne predyspozycje do takich osiągnięć) w tej czy innej dziedzinie (Cechy szczególne pracy...).

W edukacji szkolnej w odniesieniu do jednostek przejawiających wysoki poziom zdolności ogólnych lub zdolności specjalnych mówimy o uczniach zdolnych. Charakteryzują się oni następującymi właściwościami: zdolność do efektywnego uczenia się rzeczy nowych i wybitne wyniki w jakiejś aktywności, oryginalność w myśleniu i działaniu, duże nasilenie dążeń poznawczych, przejawianie wysokiego poziomu myślenia analitycznego, łatwość rozumienia i przyswajania symboli abstrakcyjnych i stosunków symbolicznych, zdolność do koncentracji uwagi (zwłaszcza na treściach abstrakcyjnych), zainteresowania poznawcze, wrażliwość na problemy i wytrwałość w ich rozwiązywaniu, przeżywanie satysfakcji z pokonywania trudności intelektualnych (Aleksandrovich 2013, s. 38).

Identyfikacja ucznia zdolnego jest działaniem służącym ustaleniu faktów potwierdzających jego ponadprzeciętny potencjał i stanowi jedną z podstaw pełnego diagnozowania zdolności w celu ich odkrycia (Ziemski 1973 za: Kosiarek 2013).

\section{STRUKTURA ORAZ TYPY UZDOLNIEŃ MATEMATYCZNYCH}

Tematyka uzdolnień matematycznych pojawia się w psychologii w końcu XIX wieku. Bazując na definicjach Ladislava Košča (1982), Wadima Andrejewicza Krutieckiego (1971, 1980) oraz na poglądach Jacquesa Hadamarda (1964), w których system symboli jest rozumiany jako całokształt języka matematycznego, proponuję następujące ujęcie uzdolnień matematycznych: 
Jest to ukierunkowanie wszystkich procesów poznawczych, świadomych i podświadomych, które warunkuje opanowanie systemu symboli matematycznych, operowanie nimi w sposób optymalny (odbiór, pamiętanie, przetwarzanie), co w efekcie powoduje szybkie i skuteczne zyskanie nie tylko konkretnych wiadomości, ale też możliwości kreacyjnych.

Czy jednak uzdolnienia matematyczne są specyficzne?

Według Stanisława Popka (2003, s. 148) struktura ogólna uzdolnień specjalnych przedstawia się następująco: uzdolnienia percypcyjne, uzdolnienia do przechowywania informacji, uzdolnienia do przetwarzania i wytwarzania informacji nowych, wrażliwość emocjonalna, uzdolnienia wykonawcze (umiejętności). W strukturze uzdolnień matematycznych należałoby zatem uwzględnić przede wszystkim:

1. Dostrzeganie relacji i stosunków liczbowych oraz umiejętność dokonywania przekształceń w zbiorach.

2. Dostrzeganie i rozumienie obrazów i relacji przestrzennych. Działania na relacjach przestrzennych.

3. Transformacje obrazów przestrzennych, abstrakcje przestrzenne, kombinatoryka, umiejętność formułowania strategii kombinatorycznych, algorytmizacja strategii (dedukcja na bazie przesłanek).

4. Dokonywanie działań i operacji arytmetycznych oraz operacji na symbolach liczbowych, zapamiętywanie liczb.

Natomiast według Krutieckiego struktura uzdolnień matematycznych przedstawia się następująco (Krutieckij 1971, s. 257-258):

1. Odbieranie informacji matematycznych - zdolność sformalizowanego postrzegania materiału matematycznego i pojmowania struktury formalnej zadania.

2. Stosowanie wiedzy matematycznej - zdolność myślenia logicznego na materiale stosunków liczbowych i przestrzennych; zdolność myślenia za pomocą symboli matematycznych; zdolność szybkiego i znacznego uogólniania przedmiotów matematycznych, stosunków i działań; zdolność streszczania procesu rozumowania matematycznego i układu odpowiednich działań; zdolność myślenia strukturami zredukowanymi; plastyczność procesów myślowych w działaniu matematycznym; dążenie do rozwiązań jasnych, prostych, ekonomicznych i racjonalnych; zdolność szybkiego i dowolnego zmieniania kierunku procesu myślowego i przełączania myśli (odwracalność procesów myślowych w przebiegu rozumowania matematycznego). 
3. Przechowywanie informacji matematycznych, tj. pamięć matematyczna - zdolność pamiętania ogólnych stosunków matematycznych, schematów rozumowań i dowodów, metod i zasad rozwiązywania zadań.

4. Ogólny składnik syntetyczny, tj. matematyczne ukierunkowanie umysłu.

Do tych umiejętności Krutieckij dodaje jeszcze inne specyficzne dla uzdolnienia matematycznego:

1. Szybkość przebiegu procesów myślowych (matematyk może myśleć powoli, ale musi to być rozumowanie wszechstronne i głębokie).

2. Zdolności rachunkowe (wykonywanie szybkich i dokładnych obliczeń, często w pamięci).

3. Pamięć do cyfr, liczb i wzorów.

4. Wyobraźnia przestrzenna.

5. Zdolność wyobrażania sobie abstrakcyjnych stosunków i zależności (Krutieckij 1971, s. 259).

Specyficzne cechy myślenia matematycznego to: ogólność, zredukowanie, giętkość, odwracalność.

Struktura uzdolnień matematycznych świadczy o ich specyfice. Specyficzny jest także język matematyki, język symboli, znaków, liczb, punktów, linii, schematów, figur, płaszczyzn. Forma znaków determinuje sposób ich opracowania, a więc myślenia. W związku z tym wyróżnia się dwa style myślenia matematycznego: algebraiczny i geometryczny (Nosal 1977). Geometryczny związany jest bardziej z myśleniem obrazowym, natomiast algebraiczny oznacza większą koncentrację na pojęciach liczbowych.

Uzdolnienia matematyczne mogą się przejawiać w dwojaki sposób. Rozróżnia się reproduktywną i produktywną działalność matematyka, a zatem wyodrębnia się dwa stopnie rozwoju uzdolnień matematycznych: pierwszy - uzdolnienia reproduktywne (przyswajanie pojęć, opanowanie działań matematycznych), drugi - uzdolnienia twórcze (tworzenie nowych, oryginalnych produktów). Na tej podstawie wyróżnia się również dwa inne typy uzdolnień matematycznych: produktywny, czyli heurystyczny, i nieproduktywny - algorytmiczny (Gawda 1996). Osoby posiadające uzdolnienia produktywne potrafią formułować oryginalne prawa, znajdować nowe rozwiązania, a osoby z uzdolnieniami typu nieproduktywnego - tylko opanowywać znane schematy.

Jak dużo wspólnego ma szkolna matematyka z realnym matematycznym myśleniem? Krutieckij (1980) jest zdania, że podstawowe zdolności na poziomie szkolnym mogą stanowić bazę dla twórczości naukowej w zakresie matematyki. Podkreśla umiejętność wskazania problemów, poszukiwania oryginalnych dróg rozwiązania, formułowanie praw matematyki. Autor zakłada, że twórczość matematyczna może być nie tylko obiektywna, ale i subiektywna, sądzi zatem, iż wymienione czynności 
stanowią przejaw twórczości matematycznej i przyjmuje, że fakt istnienia uzdolnienia matematycznego na poziomie szkolnym nie hamuje rozwoju uzdolnienia matematycznego typu heurystycznego.

Z genezy uzdolnień matematycznych wynika, iż pojawiają się one stosunkowo wcześnie w życiu człowieka. Nie jest więc możliwe, żeby osoba uzdolniona matematycznie miała kłopoty z matematyką na poziomie szkolnym, a dopiero później rozwijała się w tym kierunku. Postępy osiąga się stopniowo. Osoba uzdolniona szybciej opanuje wymagane wiadomości, a oprócz tego może wykazywać możliwości kreacyjne. Bywa, że uzdolnienie matematyczne pojawia się już w młodszym wieku szkolnym (Hawlicki 1971), natomiast pełny jego rozwój przypada na dojrzewanie (okres operacji formalnych według Jeana Piageta). Wiąże się to z ogólnym rozwojem intelektualnym, a także pamięcią i uwagą. Czesław Nosal (1971) uważa, że moment optymalnych możliwości w zakresie matematyki odpowiada momentowi optymalnych możliwości w zakresie uwagi i pamięci. Moment ten jest tożsamy z momentem maksymalnego poziomu intelektu, który następuje w wieku 15-25 lat. Oznacza to, że okres edukacji szkolnej ma ogromne znaczenie dla rozwoju uzdolnień matematycznych.

W białoruskim systemie oświatowym przywiązuje się dużą wagę do pracy z uczniami zdolnymi, zanim jednak omówię, na czym ona polega w przypadku uczniów uzdolnionych matematycznie, scharakteryzuję system szkolnictwa na Białorusi.

\section{SYSTEM EDUKACYJNY NA BIAŁORUSI}

System edukacji na Białorusi oferuje różne ścieżki kształcenia w zależności od miejsca zamieszkania (miasto/wieś), uzdolnień, indywidualnych decyzji uczniów i ich rodziców.

Obowiązkowa edukacja szkolna rozpoczyna się w wieku 6 lat i trwa do 15. roku życia z możliwością kontynuowania nauki na dalszych szczeblach kształcenia. Etap obowiązkowy kończy się uzyskaniem świadectwa bazowego, które otrzymują absolwenci:

- czteroklasowej szkoły podstawowej, po której kontynuuje się naukę przez kolejnych pięciu lat w szkole bazowej, średniej lub gimnazjum;

- dziewięcioklasowej szkole bazowej (tylko na wsi);

- jedenastoklasowej szkole średniej lub gimnazjum, po ukończeniu dziewięciu klas (art. 11 Kodeksu Oświaty RB 2011).

Świadectwo bazowe uczniowie uzyskują po zdaniu czterech obowiązkowych egzaminów z: języka białoruskiego, języka rosyjskiego, matematyki oraz historii 
Białorusi. Pierwsze trzy egzaminy są pisemne, ostatni - ustny, i odbywają się w szkołach, jednak w terminie wspólnym dla wszystkich.

Warto zaznaczyć, że niektóre typy szkół różnicowane są ze względu na poziom kształcenia i związane z nim wymagania wobec uczniów. Szkoły średnie, rejonowe, są dostępne dla wszystkich, natomiast gimnazja tylko dla uczniów szczególnie uzdolnionych, którzy dostają się tam po zdaniu egzaminów wstępnych na poszczególnych etapach nauczania. Dzieci muszą zatem zdać pomyślnie egzamin do klasy I, potem do klasy V, przy czym ten ostatni obowiązuje zarówno uczniów gimnazjum macierzystego, jak i absolwentów klasy IV szkoły podstawowej oraz bazowej lub średniej, którzy chcą zmienić rodzaj placówki.

Aby uzyskać świadectwo maturalne (w wieku 17 lat), uczniowie kontynuują edukację w następujących typach szkół (do wyboru):

- jedenastoletniej szkole średniej lub gimnazjum (dwie ostatnie klasy),

- dwuletnim liceum,

- dwu- lub czteroletnim technikum (art. 12 Kodeksu oświaty RB 2011).

Uczniowie zatem mogą kontynuować naukę do matury w swojej szkole macierzystej, średniej lub gimnazjum, mogą również pójść do technikum lub liceum. Technika są szkołami o profilu zawodowym, w których pod uwagę brane są wyniki wewnętrznych egzaminów wstępnych oraz uwzględniana jest średnia ocen ze świadectwa bazowego. Wymagania zależą od profilu i prestiżu danego technikum. Natomiast liceum to szkoła dla uczniów o największych osiągnięciach edukacyjnych i skonkretyzowanych zainteresowaniach, wybierają oni bowiem określony profil kształcenia (np. matematyczno-fizyczny, biologiczno-chemiczny, filologiczny). Kandydaci dostają się tam na podstawie bardzo trudnych wewnętrznych egzaminów wstępnych oraz wysokiej średniej ocen ze szkoły niższego typu (gimnazjum, średniej, bazowej). Są to placówki elitarne, często mieszczące się przy uczelniach wyższych, a wykłada w nich kadra akademicka. Chętnych jest zazwyczaj kilkunastokrotnie więcej niż miejsc.

W wieku 17 lat, po ukończeniu jedenastoletniego cyklu kształcenia, uczniowie zdają egzamin maturalny z języka białoruskiego, języka rosyjskiego, matematyki, języka obcego oraz jednego z przedmiotów wybranych przez ucznia i otrzymują świadectwo dojrzałości. Po maturze ci, którzy ubiegają się o miejsce na studia wyższe, przystępują do testowych egzaminów przedmiotowych odbywających się na uczelniach. Kandydaci mogą rozpocząć studia w wieku 17 lat. Nauka w zależności od profilu uczelni trwa cztery lata lub pięć lat. Po ukończeniu studiów młody człowiek uzyskuje dyplom i tytuł zawodowy magistra. Dla wybitnych studentów posiadających dyplom ukończenia studiów wyższych są nieliczne miejsca na czteroletnich studiach doktoranckich. Można się na nie dostać po zdaniu wewnętrznych egzaminów wstępnych oraz wylegitymowaniu się wysoką średnią ocen z dyplomu. 
W sumie ciągły system kształcenia na Białorusi może trwać 20 lat (wiek 6-26 lat). Tabela 1 przedstawia graficznie system szkolnictwa białoruskiego.

Tabela 1. System szkolnictwa białoruskiego.

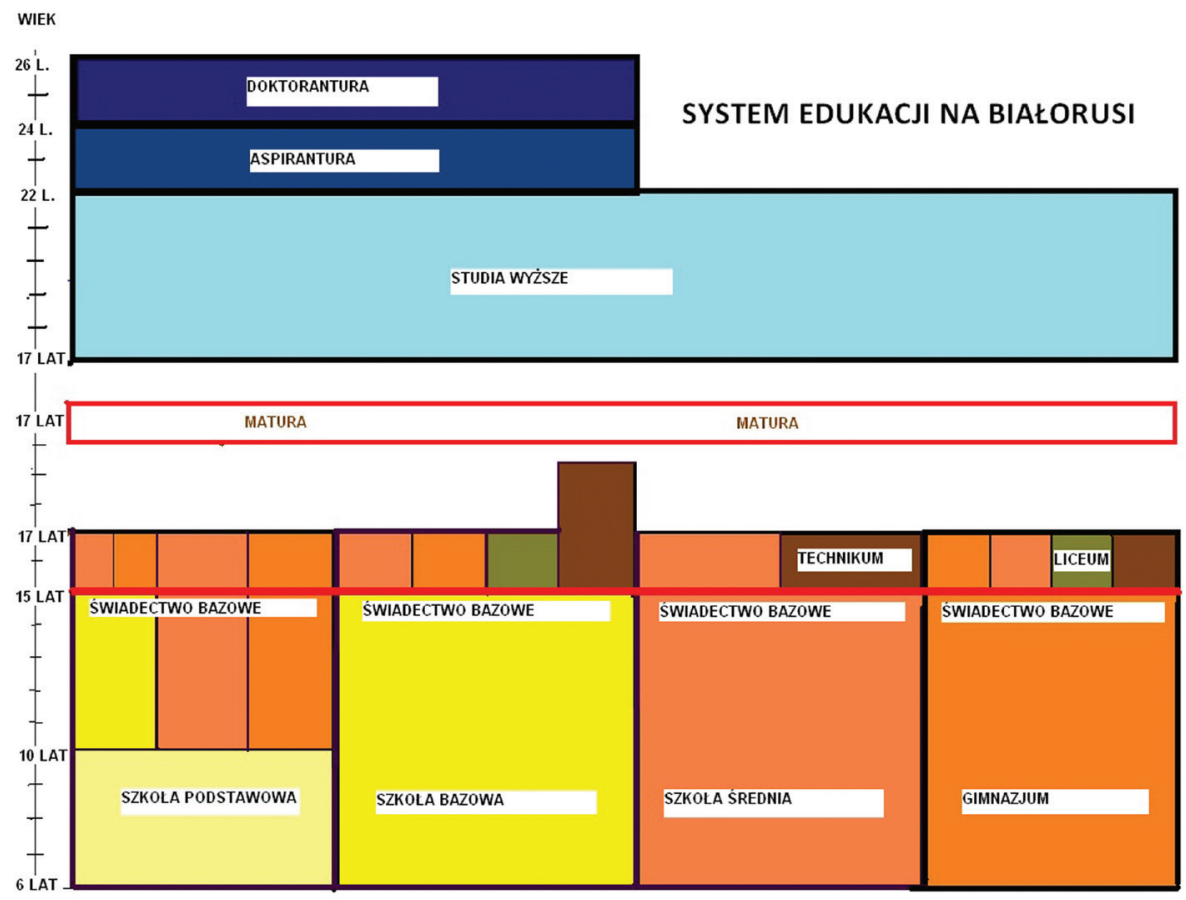

Źródło: opracowanie własne na podstawie Kodeksu oświaty RB 2011 (art. 11, 12) oraz informacji ze strony internetowej Ministerstwa Oświaty RB.

\section{WSPARCIE DZIECI UZDOLNIONYCH MATEMATYCZNIE W SZKOLE BIAŁORUSKIEJ}

Na Białorusi działa prezydencki program „Zdolne dzieci Białorusi”. Realizowany jest przez Ministerstwo Edukacji oraz Ministerstwo Kultury Białorusi. Program ma na celu rozwijanie zdolności utalentowanych dzieci. W ramach niego co roku organizowane są konkursy, olimpiady, turnieje, obozy naukowe. Przyznawane są również stypendia dla wybitnie zdolnych uczniów i studentów.

Utalentowane matematycznie dzieci w białoruskiej szkole mają możliwość rozwoju i ukazywania swojego talentu poprzez uczestniczenie w olimpiadach matematycznych oraz konkursach. Dzieci w wieku szkolnym już od II klasy szkoły podstawowej (7-8 lat) z zainteresowaniem i chęcią rozwiązują zadania twórcze 
olimpiady „Kangur”. Od VIII klasy (14-15 lat) mogą brać udział w olimpiadach przedmiotowych. Na pierwszym etapie, wewnątrzszkolnym, uzdolnione dzieci najczęściej wybierają olimpiady z kilku przedmiotów. Zwycięzcy olimpiady matematycznej uzyskują możliwość uczestniczenia w zajęciach indywidualnych oraz lekcjach prowadzonych $\mathrm{w}$ mniejszych grupach $\mathrm{z}$ nauczycielem, który przygotowuje dzieci, proponując do rozwiązania zadania o wyższym poziomie trudności. Po skończeniu cyklu takich zajęć dzieci potrafią uzyskać lepsze wyniki podczas olimpiady dzielnicowej, miejskiej, a - w razie powodzenia na tych etapach ogólnokrajowej. Uczniowie, którzy odnieśli zwycięstwo bądź zostali wyróżnieni na miejskiej lub ogólnokrajowej olimpiadzie, są zapraszani na obozy naukowe o profilu fizyczno-matematycznym. Na takich obozach uczą nie tylko nauczyciele, ale też wykładowcy z uczelni wyższych. Wyjazdy organizowane są w czasie wakacji, a wyżywienie i zakwaterowanie dla uczniów i nauczycieli finansuje państwo. Uczestnicy obozów biorą udział w procesie nauczania ponadprogramowego, kształtują matematyczne umiejętności, rozwiązując zadania o najwyższym, rozszerzonym poziomie trudności pod patronatem indywidualnym kadry akademickiej. Mogą również korzystać z zajęć organizowanych jako klasy autorskie, warsztaty, wykłady, seminaria.

Warto zaakcentować szczególną rolę szkół specjalistycznych typu gimnazjum (szkół z rozszerzonym zakresem nauczania). Można powiedzieć, że na Białorusi są przeznaczone dla dzieci utalentowanych, dlatego aby się dostać do I klasy (w wieku 6 lat), trzeba rozwiązać test zawierający zadania matematyczne i językowe, którego celem jest diagnoza poziomu rozwoju dziecka oraz - na jej podstawie - podjęcie decyzji, czy jest przygotowane do kształcenia w szkole na zaawansowanym poziomie. Jeśli test został rozwiązany pomyślnie, komisja zaprasza dziecko oraz rodziców na rozmowę kwalifikacyjną. Jej wyniki stanowią dodatkowe kryterium decydujące o przyjęciu ucznia. W ciągu pierwszych czterech lat w gimnazjum dzieci uczy jeden nauczyciel (nauczyciel szkoły podstawowej), a także nauczyciel języka obcego. W ramach zajęć dodatkowych uczniom są proponowane różnego rodzaju kółka zainteresowań (płatne oraz nieodpłatne). Po ukończeniu kursu z zakresu szkoły podstawowej zdaje się egzaminy z języka rosyjskiego, białoruskiego oraz matematyki. Wyniki muszą być dobre, żeby móc kontynuować naukę w gimnazjum. Wysokie wymagania egzaminacyjne stawiane są także dzieciom, które przez pierwsze cztery lata chodziły do innej szkoły, a od V klasy chcą uczyć się w gimnazjum.

W początkach nauki utalentowanymi matematycznie dziećmi najczęściej opiekują się nauczyciele szkoły podstawowej lub bazowej. Uczniom proponuje się zajęcia indywidualne, zajęcia fakultatywne $\mathrm{z}$ matematyki oraz zajęcia przygotowujące do uczestniczenia w olimpiadach z matematyki dla dzieci utalentowanych. Natomiast 
jeśli rodzice uważają, że to nie jest niewystarczające, mają możliwość zorganizowania zajęć odpłatnych z nauczycielem wybranym przez administrację szkoły do zajęć dodatkowych, maksymalnie rozwijających zdolności matematyczne uczniów (art. 158, pkt 17 Kodeksu oświaty RB 2011).

Od 1 września 2013 roku (Organizacja procesu edukacyjnego 2013) na Białorusi zaistniała możliwość uczenia się w profilowanych klasach w szkołach średnich. Wcześniej można było uczęszczać do klasy profilowanej tylko w gimnazjum lub liceum. Profil przedmiotowy w szkołach średnich wybiera się od X klasy', a maturę zdaje się z niego na rozszerzonym poziomie. Do wyboru w szkołach średnich uczniowie mają następujące kierunki klas profilowanych: fizyczno-matematyczny, chemiczno-biologiczny, społeczny i filologiczny.

Po uzyskaniu wykształcenia bazowego najzdolniejsi uczniowie starają się dostać do liceów prowadzonych przez uczelnie wyższe - naucza tam kadra profesorska z różnych wydziałów. W szkołach tych program matematyki jest znacznie rozbudowany. Na przykład w X-XI klasie szkoły średniej (w Polsce to II-III klasa liceum) są przewidziane $\mathrm{w}$ tygodniu 4 godziny lekcyjne $\mathrm{z}$ matematyki, natomiast w szkołach o rozszerzonym profilu nauczania oraz w liceach realizuje się 12 godzin lekcyjnych -6 godzin obowiązkowych oraz 6 godzin fakultetu (Podstawy programowe $z$ przedmiotów szkolnych... 2014). Zwiększona liczba godzin lekcyjnych z matematyki w szkołach o rozszerzonym poziomie nauczania oraz $\mathrm{w}$ liceach ma na celu przygotowanie uczniów do uczestniczenia w olimpiadach z matematyki o różnym poziomie trudności oraz do studiów na uczelniach wyższych o profilu zgodnym z wybranym wcześniej kierunkiem kształcenia.

Wybitnie utalentowani matematycznie absolwenci liceów na studiach pozostają pod opieką tych samych wykładowców uniwersyteckich, którzy dotychczas uczyli ich matematyki. Na uczelniach są przygotowani do olimpiad międzynarodowych $\mathrm{z}$ matematyki i informatyki. O tym, że system wspierania w rozwoju dzieci utalentowanych matematycznie na Białorusi jest efektywny, świadczą ich osiągnięcia.

Wskaźnik osiągnięć na olimpiadach międzynarodowych uczniów białoruskich z zakresu matematyki i informatyki w porównaniu z wynikami uczniów polskich jest podobny. Być może te dane nie mówią wprost o przewadze białoruskiego systemu wspierania dzieci uzdolnionych matematycznie w porównaniu z polskim², jednak trzeba uwzględnić różnice całego kontekstu społeczno-politycznego w obu krajach, gdyż ma on wpływ na edukację.

\footnotetext{
1 W roku szkolnym 2015/2016 klasy profilowane zostały otwarte w 1118 szkołach.

2 Szczegółowe porównanie obu systemów zostanie przedstawione w przygotowywanej rozprawie doktorskiej.
} 


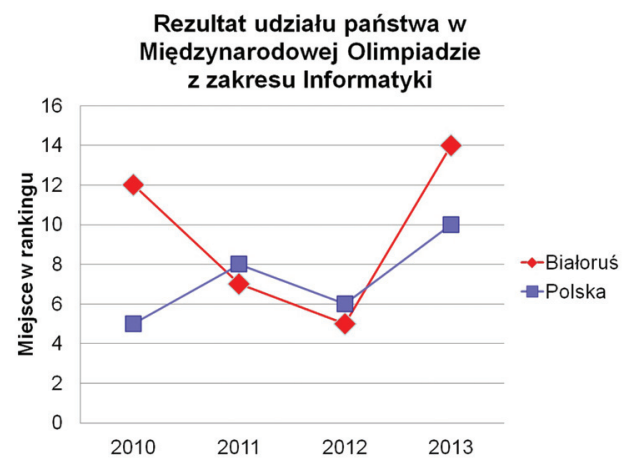

Rysunek 1. Miejsca w rankingu wyników uczniów białoruskich i polskich na Międzynarodowych Olimpiadach Informatycznych w latach 2010-2013

Źródło: Malinouskaya, Oszwa (2015). Młode talenty matematyczne w białoruskim systemie edukacji, opracowanie na podstawie danych „News, Information, Statistics: SnarkNews”

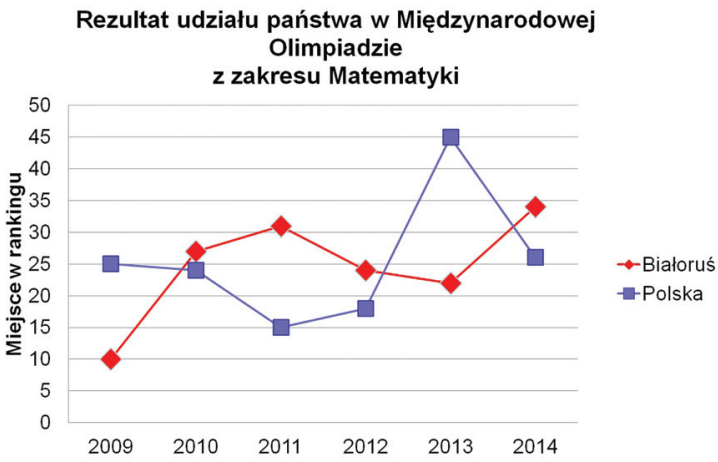

Rysunek 2. Miejsca w rankingu wyników uczniów białoruskich i polskich na

Międzynarodowych Olimpiadach Matematycznych w latach 2010-2014

Źródło: Malinouskaya, Oszwa (2015). Młode talenty matematyczne w białoruskim systemie edukacji, opracowanie na podstawie danych dostępnych na stronie internetowej International Mathematical Olympiad

\section{PODSUMOWANIE}

Białoruski system edukacji zdecydowanie należy do systemów nowoczesnych, jednak mimo to pewne jego obszary wydają się nadal bardzo efektywne. Do takich zaliczyć można wieloletnią usystematyzowaną opiekę edukacyjną nad uczniami wybitnie uzdolnionymi. O skuteczności systemu decyduje wiele czynników, m.in.:

- wczesne wykrywanie uczniów uzdolnionych w masowej edukacji, 
- zwiększona intensywność edukacji profilowanej,

- ukierunkowana opieka ośrodków akademickich nad uczniami wybitnie zdolnymi,

- założenie, że studia matematyczno-informatyczne są kontynuacją współpracy uniwersytetu ze szkołą.

\section{LITERATURA}

Aleksandrovich M., 2013, Promocja zdolności i talentów w Polsce i Europie. W: M. Aleksandrovich, B. Kołakowska (red.), Uczeń zdolny jest wśród nas. Olsztyn, Wydawnictwo Mantis.

Ciechanowski J. i in., 2010, Prawo do edukacji dzieci o specjalnych potrzebach edukacyjnych. Warszawa, Wydawnictwo Helsińska Fundacja Praw Człowieka.

Ebby J.W., Smutny J.F., 1998, Jak kształcić uzdolnienia dzieci i młodzieży. Tłum. K. Konaszewski. Warszawa, WSiP.

Gawda B., 1996, Elementy podstawy twórczej u młodzieży o zróżnicowanych uzdolnieniach matematycznych. W: S. Popek (red.), Zdolności i uzdolnienia jako osobowościowe właściwości człowieka. Lublin, Wydawnictwo UMCS.

Hadamard J., 1964, Psychologia odkryć matematycznych. Warszawa, Wydawnictwo Naukowe PWN.

Hawlicki J., 1971, Rozwijanie uzdolnień matematycznych. Warszawa, PZWS.

International Mathematical Olympiad. Poland. Team Results, opublikowano: https:// www.imo-official.org/country_team_r.aspx?code=POL [dostęp 06.03.2015].

Cechy szczególne pracy $z$ dziećmi uzdolnionymi, opublikowano: http://www.mozlicey.by/mr_odarennye.php [dostęp: 31.10.2017].

Ciechanowski J., Chmielewska B., Czyż E., Kołodziej Z. (oprac.), 2010, Prawo do edukacji dzieci o specjalnych potrzebach edukacyjnych. Raport $z$ monitoringu. Helsińska Fundacja Praw Człowieka, opublikowano: http://www.hfhr.pl/wp-content/uploads/2013/10/Monitoring_Prawo_do_edukacji_dzieci.pdf [dostęp: 31.10.2017].

Kodeks oświaty Republiki Białoruś z 13 stycznia 2011 roku, № 243-3.

Kosiarek T., 2013, Opracowanie i wdrożenie kompleksowego systemu pracy z uczniem $z$ dolnym. Wystąpienie na konferencji „Rozpoznać, wspierać, rozwijać - zdolny uczeń w systemie edukacji” w Ożarowie Mazowieckim 20 maja 2013 roku.

Košč L., 1982, Psychologia i psychopatologia zdolności matematycznych. Warszawa, Wydawnictwo Radia i Telewizji. 
Krutieckij W.A., 1971, Zagadnienia ogólne dotyczace struktury zdolności matematycznych. W: J. Strelau (red.), Zagadnienia psychologii różnic indywidualnych. Warszawa, Wydawnictwo Naukowe PWN.

Krutieckij W.A., 1980, Psichołogja matiematiczeskich sposobnostiej szkolnikow. Moskwa, Izdatielstwo Proswieszczenje.

Malinouskaya V., Oszwa U., 2015, Młode talenty matematyczne w białoruskim systemie edukacji. Wystąpienie na II Interdyscyplinarnej Konferencji Naukowej „Transgresje matematyczne” w Krakowie 15-19 marca 2015 roku.

Nosal Cz., 1977, Rola zdolności poznawczych w procesie rozwiązywania problemów. "Studia Psychologiczne”, 13, 113-130.

Organizacja procesu edukacyjnego, 2013. W: Metodiczeskije rekomendacji po organizacji izuczenia otdelnych uczebnych predmetow na powyszennom urownie w sredniej szkole, utwierzhdionnyje Ministerstwom Obrazowanija RB. „Sbornik Normatiwnych Dokumentów", nr 9.

Podstawy programowe z przedmiotów szkolnych dla instytucji edukacji ogólnokształcacej, 2014. W: Ob organizacji obrazovatelnogo processa pri izuczenii uczebnogo predmieta Matematika w uczrezhdenijach obshego srednego obrazovanija w 2014/2015 godu. Instruktiwno-metodiczeskoje pismo Ministerstwa Obrazowanija RB.

Popek S., 2002, Zdolności i uzdolnienia w świetle psychologii transgresyjnej. W: K. Szmidt, K. Piotrowski (red.), Nowe teorie twórczości. Kraków, Oficyna Wydawnicza Impuls.

Popek S., 2003, Człowiek jako jednostka twórcza. Lublin, Wydawnictwo UMCS. Ustawa z dnia 7 września 1991 r. o systemie oświaty, 2004. Dz. U., nr 256, poz. 2572 z późn. $\mathrm{zm}$.

\title{
THE MATHEMATICALLY GIFTED PUPILS IN THE BELARUSSIAN SCHOOL
}

\begin{abstract}
The Belarussian school system is one of the most traditional systems of education. Nevertheless in some areas it is still highly effective. Among them is a special form of school counselling of highly mathematically gifted pupils within the framework of talented children's personality forming program. The success of this approach is based on the Belarussian education system, which consists of various factors and approaches influencing child's development. The evidence of program's effectivity are manifested in the amount of victories of Belarussian young talents at international Math and IT contests.
\end{abstract}

Keywords: mathematical abilities, education, Belarus 